\title{
Fungicide Resistance Profiling in Botrytis cinerea Populations from Blueberry in California and Washington and Their Impact on Control of Gray Mold
}

\author{
S. Saito, United States Department of Agriculture-Agricultural Research Service (USDA-ARS), San Joaquin Valley Agricultural Sciences \\ Center, Parlier, CA 93648; T. J. Michailides, Kearney Agricultural Research and Extension Center, University of California, Parlier 93648; \\ and C. L. Xiao, USDA-ARS, San Joaquin Valley Agricultural Sciences Center
}

\begin{abstract}
Saito, S., Michailides, T. J., and Xiao, C. L. 2016. Fungicide resistance profiling in Botrytis cinerea populations from blueberry in California and Washington and their impact on control of gray mold. Plant Dis. 100:2087-2093.

Gray mold caused by Botrytis cinerea is a major postharvest disease of blueberry grown in the Central Valley of California and western Washington State. Sensitivities to boscalid, cyprodinil, fenhexamid, fludioxonil, and pyraclostrobin, representing five different fungicide classes, were examined for 249 (California) and 106 (Washington) B. cinerea isolates recovered from decayed blueberry fruit or flowers. In California and Washington, 7 and 17 fungicide-resistant phenotypes, respectively, were detected: 66 and $49 \%$ of the isolates were resistant to boscalid, 20 and $29 \%$ were moderately resistant to cyprodinil, 29 and $29 \%$ were resistant to fenhexamid, and 66 and 55\% were resistant to pyraclostrobin. All isolates from California were sensitive to fludioxonil, whereas $70 \%$ of the isolates from Washington showed reduced sensitivity to fludioxonil. In California, 26 and $30 \%$ of the isolates were resistant to two and three classes of fungicides, respectively. In Washington, 31, 14, 16, and $9 \%$ of the

isolates were resistant to two, three, four, and five classes of fungicides, respectively. Inherent risk of the development of resistance to quinone outside inhibitor (QoI) fungicides was assessed by detecting the presence of the Bcbi-143/144 intron in gene cytb. The intron was detected in 11.8 and $40 \%$ of the isolates in California and Washington, respectively, suggesting that the risk of QoI resistance is higher in California than in Washington. On detached blueberry fruit inoculated with 11 isolates exhibiting different fungicide-resistant phenotypes, most fungicides failed to control gray mold on fruit inoculated with the respective resistant phenotypes but the mixture of cyprodinil and fludioxonil was effective against all fungicide-resistant phenotypes tested. Our findings would be useful in designing and implementing fungicide resistance management spray programs for control of gray mold in blueberry.
\end{abstract}

Blueberry (Vaccinium corymbosum L.) is one of the major North American fruit crops and, more recently, has attracted much attention due to this fruit's potential health benefits and significant economic impact (Faria et al. 2005; Giacalone et al. 2011). In the United States, blueberry ranks as the second most important commercial berry crop, with a total crop value of nearly $\$ 850$ million in 2012 (Geisler 2015) and blueberry production is also steadily increasing worldwide (Brazelton 2013). Historically, the Central Valley of California is not known for production of blueberry because of mild winter weather in the region. However, recent establishment of low-chill southern highbush blueberry cultivars in California's warm climate has significantly increased the acreage of blueberry production in the region, making it now a major southern highbush blueberry production region in the United States (Jimenez et al. 2005). With rising consumption of blueberry, blueberry acreage was nearly tripled and quadrupled in California and Washington State, respectively, from 2005 to 2012 (Brazelton 2013). The vast majority of blueberry fruit grown in California are destined for the fresh market, with a 2014 production value of $\$ 119$ million (USDA-NASS 2016). As the production continues to grow, the blueberry industry has a need to prolong fruit storage life in order to extend the marketing period and increase exports. However, the postharvest life of blueberry fruit is limited by

Corresponding author: C. L. Xiao; E-mail: Chang-Lin.Xiao@ars.usda.gov

Disclaimer: Mention of trade names or commercial products in this article is solely for the purpose of providing specific information and does not imply recommendations or endorsement by the U.S. Department of Agriculture. USDA is an equal opportunity provider and employer.

Accepted for publication 22 May 2016.

http://dx.doi.org/10.1094/PDIS-02-16-0229-RE

This article is in the public domain and not copyrightable. It may be freely reprinted with customary crediting of the source. The American Phytopathological Society, 2016. fruit rots caused by fungal pathogens (Cappellini et al. 1982; Mehra et al. 2013).

Gray mold caused by Botrytis cinerea is a major, widely distributed disease of blueberry. $B$. cinerea causes blossom blight during the bloom period and fruit rot during postharvest handling and storage (Caruso and Ramsdell 2007; Fan et al. 2008; Hancock et al. 2008; Smith et al. 1996). A large number of studies focusing on postharvest technologies in blueberry have been reported, with attempts to extend market life and preserve berry quality during storage and shipment. These technologies include low-temperature storage, sulfur dioxide $\left(\mathrm{SO}_{2}\right)$ fumigation, controlled atmosphere, calcium dips, UV irradiation, ozonation, hot water, plant-originated antimicrobial agents, modified atmosphere packaging, equilibrium-modified atmosphere packaging, biodegradable package, and active packaging (Almenar et al. 2008; Alsmairat et al. 2011; Cantín et al. 2012; Duan et al. 2011; Fan et al. 2008; Hancock et al. 2008; Perkins-Veazie et al. 2008; Schotsmans et al. 2007; Wang et al. 2009). Postharvest $\mathrm{SO}_{2}$ fumigation has been commonly used to control gray mold in stored table grape (Luvisi et al. 1992), and research on blueberry has shown that $\mathrm{SO}_{2}$ fumigation is effective in controlling postharvest rots of blueberry fruit (Cantín et al. 2012). However, $\mathrm{SO}_{2}$ has not been registered for use in blueberry in the United States. Because most postharvest diseases in blueberry originate from infections in the field, one promising measure for control of postharvest diseases, including gray mold, is the use of preharvest fungicide sprays.

Several site-specific fungicides with different modes of action are available for gray mold management, including anilinopyrimidines, dicarboximides, hydroxyanilides, quinone outside inhibitors (QoI), phenylpyrroles, and succinate dehydrogenase inhibitors. However, development of fungicide resistance in the pathogen populations renders gray mold management difficult. In fact, $B$. cinerea field isolates resistant to more than one class of fungicide have been reported in various economically important crops such as apple, grape, strawberry, and various vegetables (Baroffio et al. 2003; Grabke et al. 2013; Kim and Xiao. 2010; Leroux et al. 2002; Li et al. 2014; Weber and Hahn 2011; Yin et al. 2012; Zhang et al. 2009). Understanding fungicide 
resistance profiling in B. cinerea populations is essential to the development of effective chemical control programs for gray mold. Currently, there is no information regarding fungicide resistance in $B$. cinerea in blueberry fields in California and Washington State.

QoI fungicides have recently been used increasingly either alone or in combination with fungicides from other Fungicide Resistance Action Committee codes as a premixed formulation for control of gray mold on various crops, including blueberry. Unfortunately, QoI fungicides have a high risk for selection of resistance in fungal pathogens (Leroux et al. 2002). The point mutation G143A in the cytochrome $b(c y t b)$ gene is correlated with resistance to QoI (Ishii et al. 2009). However, the presence of the Bcbi-143/144 intron in the cytb gene is thought to prevent the development of resistance to QoI; thus, isolates carrying the Bcbi-143/144 intron in cytb inherently do not develop resistance to QoI (Yin et al. 2012). Polymerase chain reaction (PCR)-based assays have been developed to detect the presence of the Bcbi-143/144 intron in cytb in fungal pathogen populations (Banno et al. 2009; Grasso et al. 2006; Yin et al. 2011). Assessing the inherent risk of resistance to QoI fungicides in $B$. cinerea populations would provide insights into the development and implementation of fungicide resistance management practices.

The objectives of this study were to (i) investigate the sensitivity to five classes of fungicides in $B$. cinerea populations from blueberry grown in California and western Washington, (ii) assess inherent risk of the selection of resistance to QoI fungicides in the $B$. cinerea populations, and (iii) evaluate the effectiveness of commercial fungicides in controlling gray mold in detached blueberry fruit incited by $B$. cinerea isolates with different fungicide-resistant phenotypes.

\section{Materials and Methods}

Isolates of $\boldsymbol{B}$. cinerea. Isolates of $B$. cinerea were collected during a survey for postharvest diseases of blueberry in 2012 and 2013. In 2012, stored blueberry fruit were collected from a packinghouse in Delano, CA. The fruit were produced from eight fields in the Central Valley of California and four fields near Blaine in western Washington. Decayed fruit were subjected to isolation of fungi from symptomatic tissues, as described below. In 2013, packed blueberry fruit were collected from four farms or packinghouses shortly after harvest. The fruit were stored at 0 to $0.5^{\circ} \mathrm{C}$ for 5 weeks, at which time isolations of causal agents from decayed fruit were attempted. In addition, isolates also were obtained from flower samples during the growing season in California in 2013.

To isolate Botrytis spp., decayed fruit were lightly sprayed with $70 \%$ ethanol and allowed to dry. The skin at the margin of symptomatic and healthy tissue was peeled off using a sterile scalpel, and three small pieces of tissue were cut and placed in petri dishes containing potato dextrose agar (PDA; Difco Laboratories, Detroit) acidified with lactic acid ( $4 \mathrm{ml}$ of $25 \%$ [vol/vol] per liter of medium) to minimize bacterial growth. Isolation plates were incubated at room temperature ( 20 to $21^{\circ} \mathrm{C}$ ) for 7 to 14 days, and Botrytis-like colonies were subcultured to new acidified PDA for 3 to 4 days. Pure isolates were then cultured on PDA. All isolates were then single-spore cultured and stored as mycelium plugs in $15 \%$ glycerol at $-80^{\circ} \mathrm{C}$ for longterm storage. All Botrytis spp. isolates were identified to species by PCR restriction fragment length polymorphism based on the $b c-h c h$ gene and phylogenetic analysis based on three genes: G3PDH, HSP60, and RPB2 (Fournier et al. 2005; Saito et al. 2014, 2016; Walker et al. 2011). In all, $98.3 \%$ of the isolates were identified as B. cinerea, and other Botrytis spp. obtained from blueberry included B. pseudocinerea, B. californica, and Botrytis spp. (Saito et al. 2014, 2016). In total, 656 isolates of $B$. cinerea were obtained in this study, including 106 isolates from Washington in 2012 and 550 isolates from California in 2012 (111 isolates) and 2013 (439 isolates).

Fungicides. For in vitro tests, five technical-grade fungicides were used. To prepare stock solutions, boscalid (99\% active ingredient [a.i.]; BASF Corporation, Research Triangle Park, NC), cyprodinil (98\% a.i.; Syngenta Crop Protection, Greensboro, NC), fludioxonil (93\% a.i.; Syngenta Crop Protection), and pyraclostrobin (98\% a.i.; BASF Corporation) were dissolved in $100 \%$ acetone and fenhexamid ( $95 \%$ a.i.; Arysta LifeScience, Cary, NC) was dissolved in $100 \%$ ethanol.
The seven commercial-grade fungicides and their concentrations used for the inoculation tests on detached blueberry fruit described below were Vangard WG fungicide at $0.655 \mathrm{~g} /$ liter (75\% a.i., cyprodinil; Syngenta Crop Protection, Inc., Wilmington, DE), Elevate 50WDG at $2.247 \mathrm{~g} /$ liter (50\% a.i., fenhexamid; Arysta LifeScience Corporation, Cary, NC), Cabrio EG at 1.311 g/liter (20\% a.i., pyraclostrobin; BASF Corporation, Florham, NJ), Endura 70WG at $0.776 \mathrm{~g} /$ liter ( $70 \%$ a.i., boscalid; BASF Corporation, Florham, NJ), Scholar SC at $1.56 \mathrm{ml} /$ liter (20.4\% a.i., fludioxonil; Syngenta Crop Protection, Inc., Wilmington, DE), Pristine at 2.153 g/liter (12.8 and $25.2 \%$ a.i., pyraclostrobin and boscalid, respectively; BASF Corporation, Florham, NJ), and Switch at $1.311 \mathrm{~g} /$ liter (37.5 and 25\% a.i., cyprodinil and fludioxonil, respectively; Syngenta Crop Protection, Inc., Wilmington, DE). Although Scholar SC is not a fungicide registered for use in blueberry, it was included to evaluate the efficacy of fludioxonil alone. Concentrations of Cabrio EG, Elevate 50WDG, Pristine, and Switch were based on fungicide label recommended rates for blueberry, while the concentrations of Vangard WG, Endura 70WG, and Scholar SC were adjusted to the same concentrations as one of the two active ingredients in the fungicide mixtures Pristine or Switch.

In vitro fungicide sensitivity tests. In total, 355 isolates were used in the in vitro fungicide sensitivity tests: 249 and 106 isolates from California and Washington, respectively. Sensitivities of B. cinerea isolates to five classes of fungicides were tested following the procedures described by Weber and Hahn (2011), with some modifications. Fenhexamid and fludioxonil were tested on $1 \%$ malt extract agar (MEA). For pyraclostrobin, the alternative oxidase inhibitor salicyl hydroxamic acid was added to MEA at $100 \mu \mathrm{g} / \mathrm{ml}$ (Mondal et al. 2005; Wise et al. 2008). In order to exclude amino acids from the cyprodinil assay (Myresiotis et al. 2007), 0.5\% sucrose agar was used instead of MEA. For boscalid, $0.5 \%$ yeast extract agar was used to avoid the interference of sugars with the assay (Stammler and Speakman 2006).

Conidia were harvested by flooding 1- to 2-week-old PDA cultures of $B$. cinerea growing on 9-cm-diameter petri dishes with a sterile scraper and suspended in sterile distilled water. The resultant conidial suspension was filtered through autoclaved gauze. The conidial concentration was then quantified microscopically with a hemocytometer and diluted to the desired concentration described below. Conidial suspensions were prepared immediately prior to inoculation and placed on ice until use.

For each isolate, an aliquot of $10 \mu \mathrm{l}$ of conidial suspension (approximately $1.0 \times 10^{5}$ conidia $/ \mathrm{ml}$ ) was streaked on the agar plate with or without fungicide. After 14 to $16 \mathrm{~h}$ of incubation at $20^{\circ} \mathrm{C}$ in darkness, the germ-tube growth of 20 representative conidia was measured under a microscope (OLYMPUS BH-2; Olympus America Co., Center Valley, PA). All experiments were performed twice.

The discriminatory concentration of each fungicide and the criteria for the classification of fungicide sensitivity phenotypes were based on Weber and Hahn (2011), with slight modifications. Briefly, two different concentrations for each class of fungicide used in this study were as follows: for boscalid, 1 and $50 \mathrm{mg} / \mathrm{liter}$; for cyprodinil, 1 and $25 \mathrm{mg} /$ /liter; for fenhexamid, 1 and $50 \mathrm{mg} /$ liter; for fludioxonil, 0.1 and $10 \mathrm{mg} / \mathrm{liter}$; and for pyraclostrobin, 0.1 and $10 \mathrm{mg} / \mathrm{liter}$. For boscalid, isolates with a fully grown germ tube at $1 \mathrm{mg} / \mathrm{liter}$ and more than $30 \%$ of growth relative to the control were classified as resistant, while sensitive isolates showed less than $50 \%$ of growth at $1 \mathrm{mg} / \mathrm{liter}$. For cyprodinil, isolates that showed more than $50 \%$ of growth at $1 \mathrm{mg} /$ liter and almost no growth at $25 \mathrm{mg} / \mathrm{liter}$ in relation to those grown on the control were classified as moderately resistant, whereas sensitive isolates grew less than $50 \%$ at $1 \mathrm{mg} /$ liter and showed no growth at all at $25 \mathrm{mg} / \mathrm{liter}$. For fludioxonil, isolates that grew more than $50 \%$ at $0.1 \mathrm{mg} / \mathrm{liter}$ and had almost no growth at $10 \mathrm{mg} / \mathrm{liter}$ were classified as less sensitive, while sensitive isolates showed almost no growth at $0.1 \mathrm{mg} / \mathrm{liter}$. For fenhexamid, isolates that showed more than $50 \%$ of growth at $0.1 \mathrm{mg} / \mathrm{liter}$ and less than $50 \%$ at $50 \mathrm{mg} /$ liter were classified as resistant, while sensitive isolates showed less than $50 \%$ of growth at $0.1 \mathrm{mg} /$ liter and little or no growth at $50 \mathrm{mg} /$ liter. For pyraclostrobin, isolates with a fully grown germ tube 
at $10 \mathrm{mg} /$ liter were classified as resistant, while isolates that grew less than $50 \%$ at $0.1 \mathrm{mg} / \mathrm{liter}$ were classified as sensitive.

Detection of the presence of the Bcbi-143/144 intron in the cytb gene. All isolates were used in this study. Mycelia from 1- to 2-week-old PDA cultures were used for genomic DNA extraction. Briefly, mycelia were harvested by scraping off the mycelial mats from the surface of the medium and transferred into a 2-ml centrifuge tube with a 5-mm stainless-steel bead (OPS Diagnostics, Lebanon, NJ). After shaking vigorously in a FastPrep-24 Instrument (MP Biomedicals, Santa Ana, CA) for $1 \mathrm{~min}$ at 60 cycles/s, genomic DNA was extracted using DNeasy Mini Spin Columns (Qiagen, Valencia, $\mathrm{CA}$ ) according to the manufacturer's protocol.

Two primer pairs, $137 \mathrm{~S}-\mathrm{F} / \mathrm{R}$ and 3 int-F/R, designed to detect the presence of the Bcbi-143/144 intron in the cytb gene (Yin et al. 2012), were used in this study. PCR was performed as described previously, with slight modification (Yin et al. 2012). Briefly, PCR amplifications were performed in a $10-\mu \mathrm{l}$ volume containing $10 \mathrm{ng}$ of fungal genomic DNA, $0.2 \mu \mathrm{M}$ each primer, and $5.0 \mu \mathrm{l}$ of GoTaq PCR mixture (Promega, Sunnyvale, CA). PCR was carried out in a S1000 thermal cycler (Bio-Rad, Hercules, CA) with the following conditions: an initial preheating for $3 \mathrm{~min}$ at $95^{\circ} \mathrm{C}$; followed by 35 cycles of denaturation at $94^{\circ} \mathrm{C}$ for $40 \mathrm{~s}$, annealing at $56^{\circ} \mathrm{C}$ for $40 \mathrm{~s}$, and extension at $72^{\circ} \mathrm{C}$ for $1 \mathrm{~min}$; and a final extension at $72^{\circ} \mathrm{C}$ for $5 \mathrm{~min}$. The PCR products were mixed with $0.2 \mu \mathrm{l}$ of EZ-VISION (Amresco, Solon, $\mathrm{OH}$ ), and separated on $1.5 \%$ agarose gels. The gel was photographed using AlphaImager HP System (ProteinSimple, Santa Clara, CA).

Fungicide activities on inoculated fruit. Three varieties of organically grown blueberry (V. corymbosum 'Emerald', 'Rocio', and 'Star') that were not treated with synthetic fungicides, depending on the readiness for harvest during the blueberry season from April to June 2013, were used to assess the fungicidal efficacy on blueberry fruit inoculated with $B$. cinerea with different phenotypes of resistance to five classes of fungicide. Prior to the experiments, fruit were dipped into $0.5 \%$ sodium hypochlorite for $2 \mathrm{~min}$, rinsed with sterile water three times, and allowed to air dry in a fume hood. The dried fruit were taped onto petri dishes. There were 10 blueberry fruit on each plate. Three replicate plates were sprayed with each fungicide at the concentration described above using a hand sprayer. Each fungicide was sprayed at approximately $3 \mathrm{ml} /$ plate. The fruit were again allowed to dry at room temperature in a fume hood. The fruit treated with sterile water were used as nonfungicide-treated controls. Fruit were inoculated with
B. cinerea conidial suspension $4 \mathrm{~h}$ after fungicide treatment. All experiments were performed twice.

Eleven $B$. cinerea isolates that have different fungicide-resistant phenotypes were used in this study. Conidial suspensions were prepared prior to the inoculation tests, as described above. The spore concentration was adjusted to the $1.0 \times 10^{5} \mathrm{conidia} / \mathrm{ml}$. Before inoculation, a wound was made on the surface of each blueberry fruit by sticking a sterile needle in to a depth of $1 \mathrm{~mm}$. An aliquot of $1 \mu \mathrm{l}$ of $B$. cinerea conidial suspension was delivered onto the wound using a micropipette. After inoculation, petri dishes without lids were transferred onto sterile paper towels in a covered, clear plastic container. Paper towels were saturated with sterile distilled water to establish high relative humidity in the container and the containers were incubated for 5 days at $20^{\circ} \mathrm{C}$ in the dark. Five days after inoculation, disease severity on blueberry was rated visually according to the following scale: $0=$ no symptoms and $1=<25,2=25$ to $50,3=$ 50 to 75 , and $4=>75 \%$ of the blueberry fruit surface decayed. An average score was calculated for each plate (replicate). Disease incidence was calculated by dividing the number of fruit exhibiting disease symptoms by the total number of fruit.

In the fungicide activity tests, depending on the availability of blueberry varieties, two different varieties were used for the two experimental runs for each isolate. Analysis of variance indicated that there were interactions between experiment run and treatment, probably due to different varieties of blueberry used in the two separate experiments. Thus, the data from the two runs were analyzed separately using PROC GLM in SAS (version 9.4; SAS Institute, Cary, $\mathrm{SC}$ ). Means for each treatment and each isolate were separated by Tukey's highly significant difference multirange tests. Data in percentage were arcsine square-root transformed prior to analysis (Perveen and Hussain 2012).

\section{Results}

Fungicide resistance profiles. Of the $355 \mathrm{~B}$. cinerea isolates tested, 50 isolates $(20.1 \%)$ and 31 isolates $(29.2 \%)$ were moderately resistant to cyprodinil in California and Washington, respectively; there were no isolates highly resistant to cyprodinil (Table 1; Fig. 1). Isolates moderately resistant to fludioxonil were not observed. All isolates from California were highly sensitive to fludioxonil, whereas 74 isolates $(69.8 \%)$ from Washington were sensitive to fludioxonil (Table 1; Fig. 1). Weber and Hahn (2011) proposed three different groups for sensitivities to boscalid and pyraclostrobin based on tube elongation of germinating conidia: "highly sensitive", "less

Table 1. Resistance profiles of Botrytis cinerea isolates to five classes of fungicides from blueberry in California and Washington

\begin{tabular}{|c|c|c|c|c|c|c|c|c|}
\hline & & & & & \multicolumn{4}{|c|}{ Number of isolates (percentage of each phenotype) } \\
\hline \multicolumn{5}{|c|}{ Fungicide and phenotypes ${ }^{z}$} & \multicolumn{2}{|c|}{ California } & \multirow{2}{*}{$\begin{array}{l}\text { Washington } \\
2012\end{array}$} & \multirow[t]{2}{*}{ Total } \\
\hline$\overline{\mathrm{CYP}}$ & FLU & BOS & PYS & FEN & 2012 & 2013 & & \\
\hline $\mathrm{S}$ & $\mathrm{S}$ & S & $\mathrm{S}$ & $\mathrm{S}$ & $38(59.3)$ & $45(24.3)$ & $10(9.4)$ & $93(22.9)$ \\
\hline $\mathrm{S}$ & LS & $\mathrm{S}$ & $\mathrm{S}$ & $\mathrm{S}$ & $\ldots$ & $\ldots$ & 20 (18.9) & $20(6.2)$ \\
\hline $\mathrm{S}$ & $\mathrm{S}$ & $\mathrm{R}$ & S & S & $\ldots$ & $1(0.5)$ & & $1(0.3)$ \\
\hline $\mathrm{S}$ & LS & $\mathrm{R}$ & S & S & $\ldots$ & $\ldots$ & $4(3.8)$ & $4(1.2)$ \\
\hline S & $\mathrm{S}$ & S & $\mathrm{R}$ & S & $\ldots$ & $2(1.1)$ & $2(1.9)$ & $4(1.2)$ \\
\hline S & LS & S & $\mathrm{R}$ & S & $\ldots$ & $\ldots$ & 7 (6.6) & $7(2.2)$ \\
\hline$S$ & LS & $\mathrm{S}$ & S & $\mathrm{R}$ & $\ldots$ & $\ldots$ & $12(11.3)$ & $12(3.7)$ \\
\hline $\mathrm{mR}$ & LS & $\mathrm{R}$ & S & $\mathrm{S}$ & $\ldots$ & $\ldots$ & $1(0.9)$ & $1(0.3)$ \\
\hline S & LS & $\mathrm{R}$ & S & $\mathrm{R}$ & $\ldots$ & $\ldots$ & $1(0.9)$ & $1(0.3)$ \\
\hline S & $\mathrm{S}$ & $\mathrm{R}$ & $\mathrm{R}$ & $\mathrm{S}$ & $12(18.8)$ & $52(28.1)$ & $10(9.4)$ & $74(21.1)$ \\
\hline S & LS & $\mathrm{R}$ & $\mathrm{R}$ & $\mathrm{S}$ & $\ldots$ & $\ldots$ & $1(0.9)$ & $1(0.3)$ \\
\hline S & LS & $\mathrm{S}$ & $\mathrm{R}$ & $\mathrm{R}$ & $\ldots$ & $\ldots$ & $3(2.8)$ & $3(0.9)$ \\
\hline $\mathrm{mR}$ & $\mathrm{S}$ & $\mathrm{R}$ & $\mathrm{R}$ & $\mathrm{S}$ & $8(12.5)$ & $18(9.7)$ & $6(5.7)$ & $32(8.7)$ \\
\hline $\mathrm{mR}$ & LS & $\mathrm{R}$ & $\mathrm{R}$ & $\mathrm{S}$ & $\ldots$ & $\ldots$ & $14(13.2)$ & $14(4.3)$ \\
\hline S & $\mathrm{S}$ & $\mathrm{R}$ & $\mathrm{R}$ & $\mathrm{R}$ & $\ldots$ & $49(26.5)$ & $3(2.8)$ & $52(16.1)$ \\
\hline$S$ & LS & $\mathrm{R}$ & $\mathrm{R}$ & $\mathrm{R}$ & $\ldots$ & $\ldots$ & $2(1.9)$ & $2(0.6)$ \\
\hline $\mathrm{mR}$ & $S$ & $\mathrm{R}$ & $\mathrm{R}$ & $\mathrm{R}$ & $6(9.4)$ & $18(9.8)$ & $1(0.9)$ & $25(6.8)$ \\
\hline $\mathrm{mR}$ & LS & $\mathrm{R}$ & $\mathrm{R}$ & $\mathrm{R}$ & $\ldots$ & ... & $9(8.5)$ & $9(2.8)$ \\
\hline
\end{tabular}

${ }^{\mathrm{z}} \mathrm{CYP}=$ cyprodinil, FLU $=$ fludioxonil, $\mathrm{BOS}=$ boscalid, $\mathrm{PYS}=$ pyraclostrobin, $\mathrm{FEN}=$ fenhexamid. $\mathrm{S}=$ sensitive, $\mathrm{LS}=$ less sensitive, $\mathrm{mR}=$ moderately resistant, and $\mathrm{R}=$ resistant. 
sensitive", and "highly resistant". However, in our study, there was no clear difference between highly sensitive and less sensitive; hence, we combined both groups as the "sensitive" group. Although $164(65.9 \%)$ and 165 isolates $(66.3 \%)$ were resistant to boscalid and pyraclostrobin, respectively, in California $52(49.1 \%)$ and 50 isolates (47.2\%) were resistant to the same two fungicides, respectively, in Washington (Table 1; Fig. 1). In all, 73 (29.3\%) and 31 isolates (29.2\%) were resistant to fenhexamid in California and Washington, respectively (Table 1; Fig. 1).

Of the 355 isolates examined, four and seven fungicide-resistant phenotypes were detected in the populations from California in 2012 and 2013, respectively, whereas 17 fungicide-resistant phenotypes were observed in the population from Washington in 2012 (Table 1). The high number of fungicide-resistant phenotypes in the Washington population appeared to be attributed to the presence of isolates that were less sensitive to fludioxonil (Table 1).

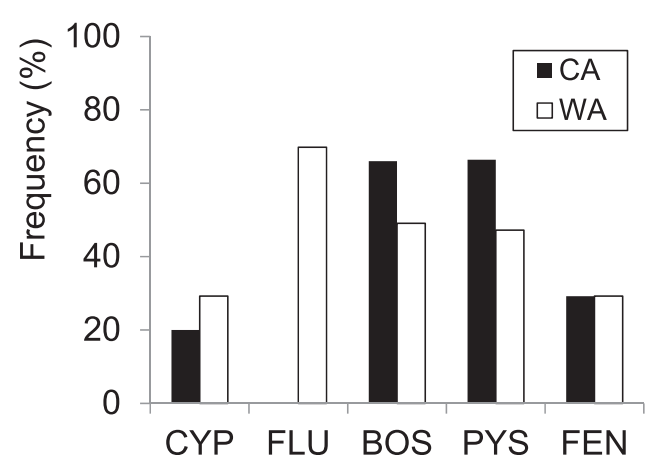

Fig. 1. Frequency of Botrytis cinerea isolates resistant to boscalid (BOS), pyraclostrobin (PYS), and fenhexamid (FEN); moderately resistant to cyprodinil (CYP); and less sensitive to fludioxonil (FLU) in California (CA) and Washington (WA).
Inherent risk of QoI resistance. All B. cinerea isolates collected from blueberry fields in California and Washington were examined for the presence of the Bcbi-143/144 intron in the cytb gene. Of the 550 isolates collected in California, 65 (11.8\%) harbored the Bcbi-143/144 intron, whereas 42 of the 106 isolates $(40.0 \%)$ collected in Washington harbored the same intron. All of the isolates harboring the Bcbi-143/144 intron were sensitive to pyraclostrobin, according to the in vitro fungicide sensitivity tests conducted in this study. All pyraclostrobin-resistant isolates did not carry the Bcbi-143/144 intron. Among the isolates not harboring the Bcbi-143/144 intron, 26.0\% (58 of 223 isolates) and $21.9 \%$ (14 of 78 isolates) of the isolates from California and Washington, respectively, were sensitive to pyraclostrobin (data not shown).

Efficacy of fungicides on inoculated fruit. Cyprodinil significantly reduced decay incidence and severity on the fruit inoculated with cyprodinil-sensitive isolates (Tables 2 and 3). Cyprodinil did not reduce decay incidence and severity on the fruit inoculated with the isolates moderately resistant to cyprodinil (X198, X186, and $\mathrm{X} 189$ ), except the severity on the fruit inoculated with X198 and X186 in the first experiment (Tables 2 and 3). Fludioxonil significantly reduced decay severity on the fruit inoculated with isolates either sensitive or less sensitive to fludioxonil, except isolate X189 (Tables 2 and 3). For incidence, however, there was not a significant reduction for some isolates less sensitive to fludioxonil (Tables 2 and 3 ). The mixture of cyprodinil and fludioxonil was effective against all fungicide-resistant phenotypes tested, even for the isolates that are resistant to one of the two fungicides in the mixture, except isolate X189 (Tables 2 and 3). Boscalid effectively controlled boscalidsensitive isolates but did not show any significant effects on boscalidresistant isolates, except isolate X141 in the second experiment (Tables 2 and 3). Similarly, pyraclostrobin significantly reduced severity of all pyraclostrobin-sensitive isolates and one pyraclostrobinresistant isolate (X203) but failed to reduce severity for the other pyraclostrobin-resistant isolates (Tables 2 and 3). The mixture of

Table 2. Gray mold severity and incidence on detached blueberry fruit that were treated with different fungicides and inoculated with different fungicide-resistant phenotypes, experiment 1

\begin{tabular}{|c|c|c|c|c|c|c|c|c|c|c|}
\hline \multirow[b]{2}{*}{ Isolate } & \multirow[b]{2}{*}{ Phenotype $^{\mathrm{x}}$} & \multirow[b]{2}{*}{ Pathogenicity $^{y}$} & \multicolumn{8}{|c|}{ Treatment } \\
\hline & & & Control & CYP & FLU & CYP+FLU & BOS & PYS & BOS+PYS & FEN \\
\hline \multirow[t]{2}{*}{$\mathrm{X} 203$} & CYPS LLU $^{S}$ BOS $^{S} P_{Y S}{ }^{S} F_{N}{ }^{S}$ & Severity & $4.00 \mathrm{a}$ & $0 \mathrm{c}$ & $0 \mathrm{c}$ & $0 \mathrm{c}$ & $0.77 \mathrm{~b}$ & $1.10 \mathrm{~b}$ & $0.13 \mathrm{c}$ & $0 \mathrm{c}$ \\
\hline & & Incidence & $100 \mathrm{a}$ & $0 \mathrm{c}$ & $0 \mathrm{c}$ & $0 \mathrm{c}$ & $73.3 \mathrm{~b}$ & $73.3 \mathrm{~b}$ & $10.0 \mathrm{c}$ & $0 \mathrm{c}$ \\
\hline \multirow[t]{2}{*}{ X156 } & CYPSFLULS BOS $^{S} P^{L} S^{S} F E N^{S}$ & Severity & $3.80 \mathrm{a}$ & $0 \mathrm{e}$ & $1.93 \mathrm{bc}$ & $0.03 \mathrm{e}$ & $1.70 \mathrm{~cd}$ & $2.50 \mathrm{~b}$ & $1.23 \mathrm{~d}$ & $0.67 \mathrm{e}$ \\
\hline & & Incidence & $100 \mathrm{a}$ & $20.0 \mathrm{~d}$ & $86.7 \mathrm{abc}$ & $30.0 \mathrm{~d}$ & $93.3 \mathrm{ab}$ & $83.3 \mathrm{bc}$ & $66.7 \mathrm{c}$ & $10.0 \mathrm{~d}$ \\
\hline \multirow[t]{2}{*}{ X149 } & CYPSFLU $^{L S}$ BOS $^{R} P Y S^{S} F E N^{S}$ & Severity & $2.33 \mathrm{ab}$ & $0.77 \mathrm{de}$ & $1.10 \mathrm{~cd}$ & $0.57 \mathrm{de}$ & $2.40 \mathrm{a}$ & $1.50 \mathrm{c}$ & $1.67 \mathrm{bc}$ & $0.30 \mathrm{e}$ \\
\hline & & Incidence & $100 \mathrm{ab}$ & $40.0 \mathrm{c}$ & $70.0 \mathrm{ab}$ & $23.3 \mathrm{bc}$ & $100 \mathrm{a}$ & $73.3 \mathrm{~b}$ & $76.7 \mathrm{ab}$ & $10.0 \mathrm{c}$ \\
\hline \multirow[t]{2}{*}{ X208 } & CYP $^{S}$ FLU $^{L S} B_{B O S}{ }^{S} P^{2}{ }^{R} F^{S}$ & Severity & $3.77 \mathrm{a}$ & $0.10 \mathrm{~d}$ & $1.57 \mathrm{bc}$ & $0 \mathrm{~d}$ & $1.47 \mathrm{c}$ & $2.60 \mathrm{~b}$ & $1.40 \mathrm{c}$ & $0.17 \mathrm{~d}$ \\
\hline & & Incidence & $100 \mathrm{a}$ & $20.0 \mathrm{~b}$ & $73.3 \mathrm{ab}$ & $20.0 \mathrm{~b}$ & $86.7 \mathrm{a}$ & $93.3 \mathrm{a}$ & $63.3 \mathrm{ab}$ & $23.3 \mathrm{~b}$ \\
\hline \multirow[t]{2}{*}{ X140 } & CYPS $^{S}$ LU $^{L S}$ BOS $^{S} P Y S^{S} F_{E N}^{R}$ & Severity & $3.67 \mathrm{a}$ & $0.53 \mathrm{de}$ & $0.60 \mathrm{de}$ & $0.27 \mathrm{e}$ & $1.73 \mathrm{c}$ & $2.17 \mathrm{c}$ & $0.87 \mathrm{~d}$ & $3.07 \mathrm{~b}$ \\
\hline & & Incidence & $100 \mathrm{a}$ & $53.3 \mathrm{~b}$ & $43.3 \mathrm{~b}$ & $3.33 \mathrm{c}$ & $83.3 \mathrm{ab}$ & $100 \mathrm{a}$ & $50.0 \mathrm{~b}$ & $100 \mathrm{a}$ \\
\hline \multirow[t]{2}{*}{ X169 } & CYP $^{S} F_{L U}{ }^{L S} B_{B O S}{ }^{R} P Y S^{S} F E N^{R}$ & Severity & $2.60 \mathrm{ab}$ & $0.67 \mathrm{c}$ & $1.67 \mathrm{~b}$ & $0.26 \mathrm{c}$ & $2.73 \mathrm{a}$ & $1.63 \mathrm{abc}$ & $1.77 \mathrm{abc}$ & $1.03 \mathrm{bc}$ \\
\hline & 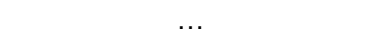 & Incidence & $83.3 \mathrm{ab}$ & $20.0 \mathrm{bc}$ & $70.0 \mathrm{ab}$ & $3.3 \mathrm{c}$ & $90.0 \mathrm{a}$ & $43.3 \mathrm{abc}$ & 63.3 & $83.3 \mathrm{a}$ \\
\hline \multirow[t]{2}{*}{ X141 } & ${ }^{C Y} P^{S}{ }_{F L U}{ }^{S} B O S^{R} P Y S^{R} F E N^{S}$ & Severity & $3.20 \mathrm{a}$ & $0.50 \mathrm{~b}$ & $0 \mathrm{~b}$ & $0.10 \mathrm{~b}$ & $2.23 \mathrm{a}$ & $2.73 \mathrm{a}$ & $2.03 \mathrm{a}$ & $0.07 \mathrm{~b}$ \\
\hline & & Incide & $100 \mathrm{a}$ & $36.7 \mathrm{bc}$ & $0 \mathrm{~d}$ & $6.7 \mathrm{~cd}$ & $83.3 \mathrm{ab}$ & $90.0 \mathrm{a}$ & $83.3 \mathrm{a}$ & $6.7 \mathrm{~cd}$ \\
\hline \multirow[t]{2}{*}{ X198 } & CYPmR ${ }^{\prime} L U^{S} B O S^{R} P Y S^{R} F E N^{S}$ & Severity & $3.70 \mathrm{a}$ & $2.47 \mathrm{~b}$ & $0 \mathrm{c}$ & $0.17 \mathrm{c}$ & $3.70 \mathrm{a}$ & $3.87 \mathrm{a}$ & $3.77 \mathrm{a}$ & $0.03 \mathrm{c}$ \\
\hline & $\ldots$ & Incidence & $100 \mathrm{a}$ & $100 \mathrm{a}$ & $0 \mathrm{c}$ & $13.3 \mathrm{~b}$ & $100 \mathrm{a}$ & $100 \mathrm{a}$ & $100 \mathrm{a}$ & $3.3 \mathrm{c}$ \\
\hline \multirow[t]{2}{*}{ X186 } & CYP $^{m R}$ FLU $^{L S} B_{B O S}{ }^{R} P^{2}{ }^{R} F E N^{S}$ & Severity & $3.90 \mathrm{a}$ & $3.47 \mathrm{~b}$ & $1.33 \mathrm{c}$ & $1.23 \mathrm{c}$ & $3.77 \mathrm{ab}$ & $3.90 \mathrm{a}$ & $3.67 \mathrm{ab}$ & $0.30 \mathrm{~d}$ \\
\hline & $\ldots$ & Incidence & $100 \mathrm{a}$ & $100 \mathrm{a}$ & $76.7 \mathrm{~b}$ & $73.3 \mathrm{~b}$ & $100 a b$ & $100 \mathrm{a}$ & $100 \mathrm{ab}$ & $6.67 \mathrm{c}$ \\
\hline \multirow[t]{2}{*}{ X137 } & ${ }^{C Y} P^{S} F_{L U}{ }^{S} B O S^{R} P Y S^{R} F E N^{R}$ & Severity & $3.67 \mathrm{a}$ & $1.27 \mathrm{~b}$ & $0.17 \mathrm{~d}$ & $0.70 \mathrm{c}$ & $3.47 \mathrm{a}$ & $3.60 \mathrm{a}$ & $3.47 \mathrm{a}$ & $3.60 \mathrm{a}$ \\
\hline & & Incidence & $100 \mathrm{a}$ & $70.0 \mathrm{~b}$ & $13.3 \mathrm{~d}$ & $36.7 \mathrm{c}$ & $100 \mathrm{a}$ & $100 \mathrm{a}$ & $100 \mathrm{a}$ & $100 \mathrm{a}$ \\
\hline \multirow[t]{2}{*}{ X189 } & CYP $^{m R}$ FLU $^{L S}{ }_{B O S}^{R}{ }^{R Y} S^{R} F E N^{R}$ & Severity & $3.13 \mathrm{ab}$ & $2.43 \mathrm{ab}$ & $2.03 \mathrm{~b}$ & $2.70 \mathrm{ab}$ & $3.70 \mathrm{a}$ & $3.50 \mathrm{a}$ & $3.40 \mathrm{a}$ & $3.00 \mathrm{ab}$ \\
\hline & $\ldots$ & Incidence $^{\mathrm{z}}$ & 100 & 93.3 & 83.3 & 93.3 & 100 & 100 & 100 & 96.7 \\
\hline
\end{tabular}

${ }^{x} \mathrm{~S}=$ sensitive, $\mathrm{R}=$ resistant, $\mathrm{LS}=$ less sensitive, $\mathrm{mR}=$ moderately resistant, $\mathrm{CYP}=$ cyprodinil, FLU = fludioxonil, $\mathrm{BOS}=$ boscalid, $\mathrm{PYS}=$ pyraclostrobin, and FEN $=$ fenhexamid.

${ }^{y}$ Disease severity was rated using a scoring scale $(0$ to 4$)$ for 30 blueberry fruit with three replicates per treatment. Incidence (\%) was calculated by dividing number of blueberry fruit exhibiting gray mold symptoms with total number of blueberry fruit $(n=30)$. Percentage data were arcsine transformed prior to analysis. Means followed by the same letter within a row are not significantly different according to Tukey's highly significant difference at $P=0.05$.

$\mathrm{z}$ There was no significant difference according to analysis of variance $(P=0.13)$. 
boscalid and pyraclostrobin significantly reduced both severity and incidence incited by the isolates that were sensitive to both fungicides, and only severity for the isolates that were resistant to one of the fungicides, except X208 (Tables 2 and 3). No significant effect of the mixture of boscalid and pyraclostrobin was observed on the dual-resistant isolates, except X141 in the second experiment (Tables 2 and 3).

Fenhexamid significantly reduced the severity and incidence incited by fenhexamid-sensitive isolates and severity for fenhexamidresistant isolates X140 and X169 on the first experiment. However, fenhexamid had no effect on the two fenhexamid-resistant isolates X137 and X189 (Tables 2 and 3).

\section{Discussion}

Weber and Hahn (2011) classified B. cinerea isolates into three or four categories, based on germ tube elongation of the fungus at two discriminatory concentrations of each fungicide. In the present study, we grouped less sensitive and sensitive isolates into the same sensitivity group for practical purposes, with fludioxonil being the exception. The three groups based on fludioxonil sensitivity proposed by Weber and Hahn (2011) are highly sensitive, sensitive, and "moderately resistant". Although we did not find any isolates moderately resistant to fludioxonil among our $B$. cinerea collection, we initially classified isolates into these groups.

However, when the two groups of isolates (sensitive and highly sensitive) were inoculated on fludioxonil-treated blueberry fruit, there was a clear difference between these two groups. For instance, the average of the disease incidence for the sensitive isolates was 71.9 and $81.4 \%$ for experiments 1 and 2, respectively, while that for the highly sensitive isolates was 3.3 and $4.2 \%$, respectively (Tables 2 and 3). There was always a significant difference in disease severity compared with the control for both highly sensitive and sensitive isolates, except isolate X189. However, when the percentage of disease severity was calculated in relation to that of the control for each isolate, the averages of relative disease severity for sensitive isolates were 45.6 and $44.4 \%$ for experiments 1 and 2, respectively, and for the highly sensitive isolates were 1.2 and $0.8 \%$, respectively (Tables 2 and 3). Hence, we revised the phenotypes used by Weber and Hahn (2011) for fludioxonil from highly sensitive and sensitive to sensitive and less sensitive, respectively, from a practical perspective.

Isolates of $B$. cinere $a$ resistant or moderately resistant to cyprodinil have also been reported elsewhere. For instance, 27.2\% of 63 isolates collected from small fruit in Germany, $12 \%$ of 165 isolates collected from vegetables in Spain, and 47\% of 217 isolates collected from small fruit in North and South Carolina (Fernández-Ortuño et al. 2013; Moyano et al. 2004; Weber 2011) were resistant or moderately resistant to cyprodinil. In our study, only moderate resistance to cyprodinil was observed. However, in the control study on detached fruit, the averages of disease severity on blueberry fruit inoculated with the three moderately resistant isolates relative to that of the nontreated control were 77.8 and $79.0 \%$ in the experiments 1 and 2, respectively, suggesting that moderate resistance could be high enough to render this fungicide ineffective against the moderately resistant isolates. This result supports the previous report where isolates moderately resistant and resistant to cyprodinil were equally pathogenic and virulent on both in vitro and detached-fruit assays; thus, such distinction appeared to be only of academic value (Fernández-Ortuño et al. 2013).

In the United States, the mixture of cyprodinil and fludioxonil has been considered effective against $B$. cinerea because resistance to fludioxonil has either not been observed or observed at very low frequency. For instance, Zhao et al. (2010) identified one fludioxonilresistant isolate among $124 \mathrm{~B}$. cinerea isolates collected from apple orchards and pear fruit between 2001 and 2003, and concluded that B. cinerea could be effectively controlled by this fungicide. More recently, Li et al. (2014) reported that, among 412 isolates collected from strawberry and blackberry fields, only 2 isolates less sensitive and 2 isolates resistant to fludioxonil were observed. In our study, whereas all the isolates in California were found to be sensitive to

Table 3. Gray mold severity and incidence on detached blueberry fruit that were treated with different fungicides and inoculated with different fungicide-resistant phenotypes, experiment 2

\begin{tabular}{|c|c|c|c|c|c|c|c|c|c|c|}
\hline \multirow[b]{2}{*}{ Isolate } & \multirow[b]{2}{*}{ Phenotype $^{x}$} & \multirow[b]{2}{*}{ Pathogenicity $^{\mathbf{y}}$} & \multicolumn{8}{|c|}{ Treatment } \\
\hline & & & Control & CYP & FLU & $\begin{array}{c}\text { CYP+ } \\
\text { FLU }\end{array}$ & BOS & PYS & $\begin{array}{c}\text { BOS+ } \\
\text { PYS }\end{array}$ & FEN \\
\hline \multirow[t]{2}{*}{$\mathrm{X} 203$} & CYPSFLUSBOSSPYSSFENS $^{S}$ & Severity & $3.60 \mathrm{a}$ & $0 \mathrm{~d}$ & $0 \mathrm{~d}$ & $0 \mathrm{~d}$ & $0.43 \mathrm{c}$ & $0.80 \mathrm{~b}$ & $0.30 \mathrm{~cd}$ & $0 \mathrm{~d}$ \\
\hline & & Incidence & $100 \mathrm{a}$ & $0 \mathrm{~d}$ & $0 \mathrm{~d}$ & $0 \mathrm{~d}$ & $40.0 \mathrm{bc}$ & $60.0 \mathrm{~b}$ & $30.0 \mathrm{c}$ & $0 \mathrm{~d}$ \\
\hline \multirow[t]{2}{*}{ X156 } & CYPS FLU $^{L S}{ }_{B O S}^{S} P_{Y S}^{S} F_{E N}^{S}$ & Severity & $3.67 \mathrm{a}$ & $0 \mathrm{~d}$ & $2.17 \mathrm{~b}$ & $0.03 \mathrm{~d}$ & $1.37 \mathrm{c}$ & $2.10 \mathrm{~b}$ & $0.97 \mathrm{c}$ & $0.37 \mathrm{~d}$ \\
\hline & 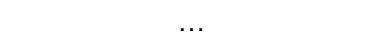 & Incidence & $100 \mathrm{a}$ & $0 \mathrm{~d}$ & $83.3 \mathrm{~b}$ & $3.3 \mathrm{~d}$ & $70.0 \mathrm{~b}$ & $83.3 \mathrm{~b}$ & $56.7 \mathrm{~b}$ & $23.3 \mathrm{c}$ \\
\hline \multirow[t]{2}{*}{ X149 } & $\mathrm{CYP}^{\mathrm{S}} \mathrm{FLU}^{\mathrm{LS}} \mathrm{BOS}^{\mathrm{R}} \mathrm{PYS}^{\mathrm{S}} \mathrm{FEN}^{\mathrm{S}}$ & Severity & $2.67 \mathrm{ab}$ & $0.40 \mathrm{de}$ & $1.20 \mathrm{~cd}$ & $0.23 \mathrm{de}$ & $2.76 \mathrm{a}$ & $1.80 \mathrm{ab}$ & $1.73 \mathrm{bc}$ & $0.13 \mathrm{e}$ \\
\hline & & Incidence & $100 \mathrm{a}$ & $56.7 \mathrm{bc}$ & $76.7 \mathrm{~b}$ & $40.0 \mathrm{c}$ & $100 \mathrm{a}$ & $96.7 \mathrm{a}$ & $100 \mathrm{a}$ & $30.0 \mathrm{c}$ \\
\hline \multirow[t]{2}{*}{ X208 } & 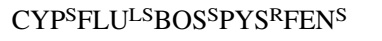 & Severity & $3.77 \mathrm{a}$ & $0.20 \mathrm{de}$ & $1.70 \mathrm{c}$ & $0.30 \mathrm{de}$ & $0.90 \mathrm{~d}$ & $3.00 \mathrm{~b}$ & $0.77 \mathrm{de}$ & $0.03 \mathrm{e}$ \\
\hline & & Incidence & $100 \mathrm{a}$ & $20.0 \mathrm{bc}$ & $93.3 \mathrm{a}$ & $30.0 \mathrm{~b}$ & $53.3 \mathrm{~b}$ & $100 \mathrm{a}$ & $43.3 \mathrm{~b}$ & $3.3 \mathrm{c}$ \\
\hline \multirow[t]{2}{*}{$\mathrm{X} 140$} & CYP $^{S}$ FLU $^{L S}{ }_{B O S}{ }^{S} P_{S}{ }^{S} F^{R}{ }^{R}$ & Severity & $3.57 \mathrm{a}$ & $0.53 \mathrm{de}$ & $0.57 \mathrm{de}$ & $0.10 \mathrm{e}$ & $1.76 \mathrm{c}$ & $2.37 \mathrm{bc}$ & $0.93 \mathrm{~d}$ & $3.13 \mathrm{ab}$ \\
\hline & & Incidence & $100 \mathrm{a}$ & $50.0 \mathrm{~b}$ & $53.3 \mathrm{~b}$ & $26.7 \mathrm{~b}$ & $96.7 \mathrm{a}$ & $96.7 \mathrm{a}$ & $56.7 \mathrm{~b}$ & $100 \mathrm{a}$ \\
\hline \multirow[t]{2}{*}{ X169 } & CYP $^{S}$ FLU $^{L S}{ }_{B O S}{ }^{R} P Y S^{S} F E N^{R}$ & Severity & $1.70 \mathrm{a}$ & $0.20 \mathrm{c}$ & $0.80 \mathrm{bc}$ & $0.03 \mathrm{c}$ & $1.43 \mathrm{ab}$ & $0.53 \mathrm{c}$ & $0.73 \mathrm{bc}$ & $1.53 \mathrm{ab}$ \\
\hline & & Incidence & $100 \mathrm{a}$ & $56.7 \mathrm{bc}$ & $83.3 \mathrm{ab}$ & $26.7 \mathrm{c}$ & $100 \mathrm{a}$ & $86.7 \mathrm{ab}$ & $83.3 \mathrm{ab}$ & $83.3 \mathrm{ab}$ \\
\hline \multirow[t]{2}{*}{ X141 } & CYP $^{S}$ FLU $^{S}{ }_{B O S}{ }^{R} P Y S^{R} F E N^{S}$ & Severity & $2.90 \mathrm{a}$ & $0.03 \mathrm{c}$ & $0 \mathrm{c}$ & $0 \mathrm{c}$ & $2.10 \mathrm{~b}$ & $2.53 \mathrm{ab}$ & $2.10 \mathrm{~b}$ & $0 \mathrm{c}$ \\
\hline & & Incidence & $100 \mathrm{a}$ & $3.3 \mathrm{~b}$ & $0 \mathrm{~b}$ & $0 \mathrm{~b}$ & $100 \mathrm{a}$ & $100 \mathrm{a}$ & $100 \mathrm{a}$ & $0 \mathrm{~b}$ \\
\hline \multirow[t]{2}{*}{ X198 } & 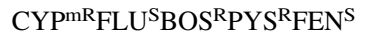 & Severity & $3.53 \mathrm{a}$ & $2.33 \mathrm{~b}$ & $0 \mathrm{c}$ & $0.23 \mathrm{c}$ & $3.50 \mathrm{a}$ & $3.73 \mathrm{a}$ & $3.67 \mathrm{a}$ & $0 \mathrm{c}$ \\
\hline & $\ldots$ & Incidence & $100 \mathrm{a}$ & $100 \mathrm{a}$ & $0 \mathrm{c}$ & $23.3 \mathrm{~b}$ & $100 \mathrm{a}$ & $100 \mathrm{a}$ & $100 \mathrm{a}$ & $6.7 \mathrm{c}$ \\
\hline \multirow[t]{2}{*}{$\mathrm{X} 186$} & CYP $^{m R}{ }^{2} L U^{L S} B_{B O S}^{R} P_{Y S}{ }^{R} F E N^{S}$ & Severity & $3.73 \mathrm{a}$ & $3.53 \mathrm{a}$ & $1.20 \mathrm{~b}$ & $1.20 \mathrm{~b}$ & $3.67 \mathrm{a}$ & $3.73 \mathrm{a}$ & $3.57 \mathrm{a}$ & $0.10 \mathrm{c}$ \\
\hline & & Incidence & $100 \mathrm{a}$ & $100 \mathrm{a}$ & $80.0 \mathrm{~b}$ & $70.0 \mathrm{~b}$ & $100 \mathrm{a}$ & $100 \mathrm{a}$ & $100 \mathrm{a}$ & $3.3 \mathrm{c}$ \\
\hline \multirow[t]{2}{*}{ X137 } & CYP $^{S}$ FLU $^{S} B O S^{R} P Y S^{R} F E N^{R}$ & Severity & $3.93 \mathrm{a}$ & $1.23 \mathrm{~b}$ & $0.13 \mathrm{c}$ & $0.60 \mathrm{c}$ & $3.77 \mathrm{a}$ & $3.80 \mathrm{a}$ & $3.83 \mathrm{a}$ & $3.47 \mathrm{a}$ \\
\hline & & Incidence & $100 \mathrm{a}$ & $83.3 \mathrm{ab}$ & $16.7 \mathrm{c}$ & $60.0 \mathrm{~b}$ & $100 \mathrm{a}$ & $100 \mathrm{a}$ & $100 \mathrm{a}$ & $100 \mathrm{a}$ \\
\hline \multirow[t]{2}{*}{ X189 } & 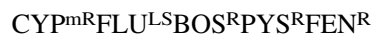 & Severity & $3.70 \mathrm{ab}$ & $2.83 \mathrm{bc}$ & $2.47 \mathrm{c}$ & $2.47 \mathrm{c}$ & $3.37 \mathrm{abc}$ & $3.77 \mathrm{a}$ & $2.67 \mathrm{c}$ & $3.27 \mathrm{abc}$ \\
\hline & $\ldots$ & Incidence $^{\mathrm{z}}$ & 100 & 100 & 100 & 96.7 & 100 & 100 & 100 & 100 \\
\hline
\end{tabular}

x $\mathrm{S}=$ sensitive, $\mathrm{R}=$ resistant, $\mathrm{LS}=$ lese sensitive, $\mathrm{mR}=$ moderately resistant, $\mathrm{CYP}=$ cyprodinil, FLU = fludioxonil, $\mathrm{BOS}=$ boscalid, $\mathrm{PYS}=$ pyraclostrobin, and FEN = fenhexamid.

y Disease severity was rated using a scoring scale ( 0 to 4$)$ for 30 blueberry fruit with three replicates per treatment. Incidence (\%) was calculated by dividing number of blueberry fruit exhibiting gray mold symptoms with total number of blueberry fruit $(n=30)$. Percentage data were arcsine transformed prior to analysis. Means followed by the same letter within a row are not significantly different according to Tukey's highly significant difference at $P=0.05$.

$\mathrm{z}$ There was no significant difference according to analysis of variance $(P=0.47)$. 
fludioxonil, less sensitive isolates appeared to be predominant $(69.8 \%)$ in Washington (Table 1; Fig. 1), suggesting that gray mold can still be controlled by fludioxonil in California but probably not in Washington. Thus, if a formulation containing only fludioxonil is available for commercial use, as suggested previously by FernándezOrtuño et al. (2013), it can be integrated into a spray program to control gray mold in California without exerting selection pressure on cyprodinil-resistant isolates.

According to the previous reports (Grabke et al. 2013; Weber and Hahn 2011), fenhexamid-resistant isolates were characterized by full germ-tube growth on the MEA media containing fenhexamid at 1 and $50 \mathrm{mg} / \mathrm{liter}$. In the present study, all fenhexamid-resistant isolates exhibited full germ-tube growth with fenhexamid at $1 \mathrm{mg} / \mathrm{liter}$ but the average germ tube growth relative to the control at $50 \mathrm{mg} / \mathrm{liter}$ was $22.3 \%$ (data not shown). However, when four of these isolates (X137, X140, X169, and X189) were inoculated on fenhexamidtreated detached blueberry fruit, the average disease severities relative to the control were 79.3 and $88.6 \%$ and the average disease incidences were 99.2 and $95.8 \%$ for experiments 1 and 2, respectively (Tables 2 and 3), indicating that fenhexamid appeared to be not effective against these isolates. Therefore, the isolates with a full germ-tube growth at $1 \mathrm{mg} / \mathrm{liter}$ and no more than $40 \%$ relative growth at $50 \mathrm{mg} / \mathrm{liter}$ were considered fenhexamid resistant in the present study.

Ma and Michailides (2005) examined sensitivity to fenhexamid in 234 B. cinerea isolates collected from various crops, including fig, grape, kiwifruit, pea, and squash, grown in the Central Valley of California from 2002 to 2004 and found that only 4 isolates (1.4\%) were identified as resistant to fenhexamid. Although the isolates were not collected from blueberry fields in that study, they were collected from the same region where blueberry crops are currently planted. It appeared that the frequency of fenhexamid resistance in the current $B$. cinerea populations in blueberry fields in the Central Valley of California (29.3\%) is significantly higher than that reported by Ma and Michailides (2005) a decade ago. High frequency of fenhexamid resistance has also been reported in other crops. Frequencies of fenhexamid resistance from French vineyards varied from less than $30 \%$ to more than $50 \%$ (Fillinger et al. 2008) while, in table grape fields in Chile, it was estimated at 35\% (Esterio et al. 2011). In Germany, $45 \%$ of isolates collected from small fruit fields showed fenhexamid resistance (Weber 2011).

The frequency of the isolates carrying the Bcbi-143/144 intron in California was $11.8 \%$, which was about four times lower than that in Washington (40\%). Therefore, inherent risk for the development of resistance to QoI fungicides is higher in California than in Washington. The higher inherent risk for the development of QoI resistance in the California population may, at least partially, explain the higher frequency of isolates resistant to pyraclostrobin in California compared with Washington.

Given a high frequency of dual resistance to boscalid and pyraclostrobin in the $B$. cinerea populations in both California and Washington, the use of the fungicide mixture Pristine is likely to be ineffective for controlling gray mold in blueberry in these locations. According to a recent study regarding stability and fitness among boscalidand pyraclostrobin-resistant $B$. cinerea isolates (Kim and Xiao 2011), resistance to both fungicides did not seem to impair fitness; however, it did exhibit a competitive disadvantage over the dualsensitive isolate on apple fruit after four successive inoculationreisolation transfers on fruit. Similar results were recently obtained by Veloukas et al. (2014), who also reported that dual-resistant isolates disappeared after 5 years of discontinued use of boscalid, pyraclostrobin, and the mixture thereof in kiwifruit orchards where dual-resistant isolates used to be predominant. These findings might suggest that dual-sensitive isolate could regain majority in a given population several years after the discontinued use of these fungicides.

In summary, we documented the occurrence of various fungicideresistant phenotypes in blueberry fields in California and Washington. Because fungicides remain the main tool for control of gray mold in blueberry, findings from this study will be useful in designing and implementing fungicide spray programs for control of gray mold in blueberry.

\section{Acknowledgments}

We thank S. Pelham for technical assistance and the participating blueberry growers and packinghouses for assistance in collection of disease samples.

\section{Literature Cited}

Almenar, E., Samsudin, H., Auras, R., Harte, B., and Rubino, M. 2008. Postharves shelf life extension of blueberries using a biodegradable package. Food Chem. 110:120-127.

Alsmairat, N., Contreras, C., Hancock, J., Callow, P., and Beaudry, R. 2011. Use of combinations of commercially relevant $\mathrm{O}_{2}$ and $\mathrm{CO}_{2}$ partial pressures to evaluate the sensitivity of nine highbush blueberry fruit cultivars to controlled atmospheres. HortScience 46:74-79.

Banno, S., Yamashita, K., Fukumori, F., Okada, K., Uesuksa, H., Takagaki, M., Kimura, M., and Fujimura, M. 2009. Characterization of QoI resistance in Botrytis cinerea and identification of two types of mitochondrial cytochrome $b$ gene. Plant Pathol. 58:120-129.

Baroffio, C. A., Siegried, W., and Hilber, U. W. 2003. Long-term monitoring for resistance of Botryotinia fuckeliana to anilinopyrimidine, phenylpyrrole, and hydroxyanilide fungicides in Switzerland. Plant Dis. 87:662-666.

Brazelton, C. 2013. 2012 World Blueberry Acreage and Production Report. North American Blueberry Council, Folsom, CA.

Cantín, C. M., Minas, I. S., Goulas, V., Jiménez, M., Manganaris, G. A., Michailides, T. J., and Crisosto, C. H. 2012. Sulfur dioxide fumigation alone or in combination with $\mathrm{CO}_{2}$-enriched atmosphere extends the market life of highbush blueberry fruit. Postharvest Biol. Technol. 67:84-91.

Cappellini, R. A., Ceponis, M. J., and Koslow, G. 1982. Nature and extent of losses in consumer-grade samples of blueberries in greater New York. HortScience 17:55-56.

Caruso, F. L., and Ramsdell, D. C., eds. 2007. Compendium of Blueberry and Cranberry Diseases, 2nd ed. American Phytopathological Society, St. Paul, MN

Duan, J., Wu, R., Strik, B. C., and Zhao, Y. 2011. Effect of edible coatings on the quality of fresh blueberries (Duke and Elliott) under commercial storage conditions. Postharvest Biol. Technol. 59:71-79.

Esterio, M., Ramos, C., Walker, A. S., Fillinger, S., Leroux, P., and Auger, J. 2011 Phenotypic and genetic characterization of Chilean isolates of Botrytis cinerea with different levels of sensitivity to fenhexamid. Phytopathol. Mediterr. 50: 414-420.

Fan, L., Forney, C. F., Doucette, C., Jordan, M. A., McRae, K. B., and Walker, B. A. 2008. Effects of hot water treatments on quality of highbush blueberries. J. Food Sci. 73:M292-M297.

Faria, A., Oliveira, J., Neves, P., Gameiro, P., Santos-Buelga, C., De Freitas, V., and Mateus, N. 2005. Antioxidant properties of prepared blueberry (Vaccinium myrtillus) extracts. J. Agric. Food Chem. 53:6896-6902.

Fernández-Ortuño, D., Chen, F., and Schnabel, G. 2013. Resistance to cyprodinil and lack of fludioxonil resistance in Botrytis cinerea isolates from strawberry in North and South Carolina. Plant Dis. 97:81-85

Fillinger, S., Leroux, P., Auclair, C., Barreau, C., Hajj, C. A., and Debieu, D. 2008 Genetic analysis of fenhexamid-resistant field isolates of the phytopathogenic fungus Botrytis cinerea. Antimicrob. Agents Chemother. 52:3933-3940.

Fournier, E., Giraud, T., Albertini, C., and Brygoo, Y. 2005. Partition of the Botrytis cinerea complex in France using multiple gene genealogies. Mycologia 97:1251-1267.

Geisler, M. 2015. Blueberries. Online publication. Ag Marketing Resource Center, Iowa State University. http://www.agmrc.org/commodities-products/fruits/ blueberries/

Giacalone, M., Sacco, F. D., Traupe, I., Topini, R., Forfori, F., and Giunta, F. 2011 Antioxidant and neuroprotective properties of blueberry polyphenols: A critical review. Nutr. Neurosci. 14:119-125.

Grabke, A., Fernández-Ortuño, D., and Schnabel, G. 2013. Fenhexamid resistance in Botrytis cinerea from strawberry fields in the Carolinas is associated with four target gene mutations. Plant Dis. 97:271-276.

Grasso, V., Palermo, S., Sierotzki, H., Garibaldi, A., and Gisi, U. 2006. Cytochrome $b$ gene structure and consequences for resistance to Qo inhibitor fungicides in plant pathogens. Pest Manage. Sci. 62:465-472.

Hancock, J., Callow, P., Serce, S., Hanson, E., and Beaudry, R. 2008. Effect of cultivar, controlled atmosphere storage, and fruit ripeness on the long-term storage of highbush blueberries. HortTechnology 18:199-205.

Ishii, H., Fountaine, J., Chung, W.-H., Kansako, M., Nishimura, K., Takahashi, K., and Oshima, M. 2009. Characterisation of QoI-resistant field isolates of Botrytis cinerea from citrus and strawberry. Pest Manage. Sci. 65:916-922.

Jimenez, M., Carpenter, F., Molinar, R. H., Wright, K., and Day, K. R. 2005 Blueberry research launches exciting new California specialty crop. Calif. Agric. 59:65-69.

Kim, Y. K., and Xiao, C. L. 2010. Resistance to pyraclostrobin and boscalid in populations of Botrytis cinerea from stored apples in Washington State. Plant Dis. 94:604-612.

Kim, Y. K., and Xiao, C. L. 2011. Stability and fitness of pyraclostrobin- and boscalid-resistant phenotypes in field isolates of Botrytis cinerea from apple. Phytopathology 101:1385-1391. 
Leroux, P., Fritz, R., Debieu, D., Albertini, C., Lanen, C., Bach, J., Gredt, M., and Chapeland, F. 2002. Mechanisms of resistance to fungicides in field strains of Botrytis cinerea. Pest Manage. Sci. 58:876-888.

Li, X., Fernández-Ortuño, D., Grabke, A., and Schnabel, G. 2014. Resistance to fludioxonil in Botrytis cinerea isolates from blackberry and strawberry. Plant Dis. 104:724-732.

Luvisi, D., Shorey, H., Smilanick, J. L., Thompson, J., Gump, B. H., and Knutson, J. 1992. Sulfur dioxide fumigation of table grapes. Univ. Calif. Div. Agric. Nat. Res. Bull. 1932

Ma, Z., and Michailides, T. J. 2005. Genetic structure of Botrytis cinerea populations from different host plants in California. Plant Dis. 89:10831089.

Mehra, L. K., MacLean, D. D., Savelle, A. T., and Scherm, H. 2013. Postharvest disease Development on southern highbush blueberry fruit in relation to berry flesh type and harvest method. Plant Dis. 97:213-221.

Mondal, S. N., Bharia, A., Shilts, T., and Timmer, L. W. 2005. Baseline sensitivities of fungal pathogens of fruit and foliage of citrus to azoxystrobin, pyraclostrobin, and fenbuconazole. Plant Dis. 89:1186-1194.

Moyano, C., Gómez, V., and Melgarejo, P. 2004. Resistance to pyrimethanil and other fungicides in Botrytis cinerea populations collected on vegetable crops in Spain. J. Phytopathol. 152:484-490.

Myresiotis, C. K., Karaoglanidis, G. S., and Tzavella-Klonari, K. 2007. Resistance of Botrytis cinerea isolates from vegetable crops to anilinopyrimidine, phenylpyrrole, hydroxyanilide, benzimidazole, and dicarboximide fungicides. Plant Dis. 91: 407-413.

Perkins-Veazie, P., Collins, J. K., and Howard, L. 2008. Blueberry fruit response to postharvest application of ultraviolet radiation. Postharvest Biol. Technol. 47: 280-285.

Perveen, F., and Hussain, Z. 2012. Review: Use of statistical techniques in analysis of biological data. Basic Res. J. Agric. Sci. Rev. 1:1-10.

Saito, S., Margosan, D., Michailides, T. J., and Xiao, C. L. 2016. Botrytis californica, a new cryptic species in the $B$. cinerea species complex causing gray mold in blueberries and table grapes. Mycologia 108:330-343.

Saito, S., Michailides, T. J., and Xiao, C. L. 2014. First report of Botrytis pseudocinerea causing gray mold on blueberry in North America. Plant Dis. 98:1743.

Schotsmans, W., Molan, A., and MacKay, B. 2007. Controlled atmosphere storage of rabbiteye blueberries enhances postharvest quality aspects. Postharvest Biol. Technol. 44:277-285.
Smith, B. J., Magee, J. B., and Gupton, C. L. 1996. Susceptibility of rabbiteye blueberry cultivars to postharvest disease. Plant Dis. 80:215-217.

Stammler, G., and Speakman, J. 2006. Microtiter method to test the sensitivity of Botrytis cinerea to boscalid. J. Phytopathol. 154:508-510.

USDA-NASS. 2016. 2014 State Agriculture True Overview. Online publication. United States Department of Agriculture National Agricultural Statistics Service. https://www.nass.usda.gov/Quick_Stats/Ag_Overview/stateOverview. php?state=California

Veloukas, T., Kalogeropoulou, P., Markoglou, A. N., and Karaoglanidis, G. S. 2014. Fitness and competitive ability of Botrytis cinerea field-isolates with dual resistance to SDHI and QoI fungicides, associated with several $s d h \mathrm{~B}$ and the cytb G134A mutations. Phytopathology 104:347-356.

Walker, A. S., Gautier, A. L., Confais, J., Martinho, D., Viaud, M., Le, P., Cheur, P., Dupont, J., and Fournier, E. 2011. Botrytis pseudocinerea, a new cryptic species causing gray mold in French vineyards in sympatry with Botrytis cinerea. Phytopathology 101:1433-1445.

Wang, C. Y., Chen, C.-T., and Wang, S. Y. 2009. Changes of flavonoid content and antioxidant capacity in blueberries after illumination with UV-C. Food Chem. 117:426-431.

Weber, R. W. S. 2011. Resistance of Botrytis cinerea to multiple fungicides in Northern German small-fruit production. Plant Dis. 95:1263-1269.

Weber, R. W. S., and Hahn, M. 2011. A rapid and simple method for determining fungicide resistance in Botrytis. J. Plant Dis. Prot. 118:17-25.

Wise, K. A., Bradley, C. A., Pasche, J. S., Gudmestad, N. C., Dugan, F. M., and Chen, W. 2008. Baseline sensitivity of Ascochyta rabiei to azoxystrobin, pyraclostrobin, and boscalid. Plant Dis. 92:295-300.

Yin, Y. N., Kim, Y. K., and Xiao, C. L. 2011. Molecular characterization of boscalid resistance in field isolates of Botrytis cinerea from apple. Phytopathology 101:986-995.

Yin, Y. N., Kim, Y. K., and Xiao, C. L. 2012. Molecular characterization of pyraclostrobin resistant and structural diversity of the cytochrome $b$ gene in Botrytis cinerea from apple. Phytopathology 102:315-322.

Zhang, C. Q., Hu, J. L., Wei, F. L., and Zhu, G. N. 2009. Evolution of resistance to different classes of fungicides in Botrytis cinerea from greenhouse vegetables in eastern China. Phytoparasitica 37:351-359.

Zhao, H., Kim, Y. K., Huang, L., and Xiao, C. L. 2010. Resistance to thiabendazole and baseline sensitivity to fludioxonil and pyrimethanil in Botrytis cinerea populations from apple and pear in Washington State. Postharvest Biol. Technol. 56:12-18. 